Ивана 3. Митић $^{1}$

Примљен: 17. фебруара 2021.

Прихваћен: 31. марта 2021. https://doi.org/10.46630/phm.13.2021.48

Универзитет у Нишу

Филозофски факултет ${ }^{2}$

Департман за србистику

Андреј И. Благојевић

Универзитет у Нишу

Филозофски факултет

Департман за комуникологију и новинарство

\title{
АНАЛИЗА РОДНО ОСЕТЉИВИХ ТЕРМИНА У ПРАВНИМ ДОКУМЕНТИМА
}

\begin{abstract}
У овом раду анализирамо родно осетљиве термине у документима законодавно-правног стила српског језика из две перспективе: из лингвостилистичке перспективе истражујемо језичка средства којима се именују женска звања и занимања у правним документима, док из перспективе правне регулативе разматрамо активности које правни документи доносе са циљем спровођења родне равноправности. Циљ истраживања је да се утврде сва могућа језичка средстава за остваривање родне равноправности у правним документима, те да се препознају разлози који доприносе употреби таквих средстава. Резултати лингвостилистичке анализе потврђују да се у правним документима употребљавају родно осетљиви термини исказани морфолошким и синтаксичким средствима, као и да су синтаксичка средства бројнија. Синтаксичка средства употребљавају се у случајевима када: 1) морфолошка форма није лексикализована, 2) морфолошка форма има више значења, 3) морфолошка форма има и негативно значење. Резултати из угла законодавно-правног оквира потврђују да су захтеви изнети у правним документима ограничени на само један домен језичких средстава. На основу анализе захтева које правни документи прокламују, а у складу са доступним језичким средствима употребљеним у њима, закључили смо да би захтеве који се тичу језичких средстава требало проширити како би се родна равноправност неометано реализовала у свим сферама друштва.
\end{abstract}

Кључне речи: лингвостилистика, правна регулатива, законодавно-правни

1 ivana.mitic@filfak.ni.ac.rs

2 Ово истраживање подржало је Министарство просвете, науке и технолошког развоја Републике Србије (Уговор бр. 451-03-9/2021-14/200165). 
стил, родно осетљиви термини, обезличеност

\section{1. Увод}

У овоме раду истражујемо употребу родно осетљивих термина у правним документима из два угла. Из угла лингвостилистике разматрамо језичка средства којима се именују женска звања и занимања у правним документима. Из перспективе оквира законодавног система Републике Србије испитујемо којим је законским документима и на који начин регулисана употреба родно осетљивих термина како би се остварила равноправност међу половима. Наше истраживање је квалитативно истраживање и циљ нам је да утврдимо на који начин се и помоћу којих језичких средстава исказује родна равноправност у правним документимa.

Родно осетљивим терминима на материјалу српског језика из угла социолингвистике бавила се Ј. Филиповић (2009), из угла родних студија понајвише С. Савић (1995; 1996), а лингвистички аспект употребе ових термина разматрали су, између осталих, М. Ивић (1960; 1989), Б. Ћорић (2008), те у новије време Н. Игњатовић (2017). У овим истраживањима, колико је нама познато, није довођена у везу употреба родно осетљивих термина са конкретним захтевима правних докумената, те са њиховом природом и правилима, нити са природом и правилима других стилова српског језика у којима се ови термини употребљавају. С обзиром на то да је ово питање језичко, социолингвистичко и правно, чињеница да није истражено у свом пуном потенцијалу и из свих углова може да допринесе не само негативној процени реализације правила изнетих у правним документима него и да има утицај на остваривање родне равноправности у свим сферама друштва. У нашем раду, из тог разлога, употребу родно осетљивих термина истражујемо из угла лингвостилистике и из угла правне регулативе, не би ли смо утврдили сва могућа средства којима се родно осетљиви термини могу исказати у српском језику, као и разлоге њихове употребе.

Један од предуслова како би се Република Србија придружила Европској унији јесте остваривање родне равноправности како у правним документима, тако и у самом језику. Од правних докумената на нивоу Европе најзначајнија је Европска конвенција за заштиту људских права и основних слобода из 1950. године, која о једнакости полова говори само кроз забрану од дискриминације на основу пола. Недовољно пажње овом питању посветили су и Римски уговори о оснивању Европске економске заједнице из 1957. године (данашње Европске уније), који су пропагирали једнакост полова само посредно, кроз принцип једнаке зараде за 
једнак рад. Овај принцип имплементиран је кроз случај Дефрен против Сабене, који је представљао прекретницу по питању родне равноправности. У каснијем периоду ова област била је предмет регулисања многих аката, као нпр. Декларације Савета Европе о једнакости између жена и мушкараца из 1988, Амстердамске повеље из 1999, Повеље о основним правима ЕУ из 2000, Лисабонске повеље из 2009, и других. Од посебног значаја, како за земље чланице Европске Уније, тако посредно и за Републику Србију као земљу кандидата за чланство, јесте Женска повеља из 2010. У погледу родне равноправности у Републици Србији, поред уопштених одредби о људским правима предвиђених Уставом, а које се ослањају на Европску конвенцију за заштиту људских права и основних слобода, од великог значаја су Закон о забрани дискриминације и Закон о равноправности полова донети 2009. године. По угледу на европско законодавство, и Република Србија усвојила је Националну стратегију за поболшағе положаја жена и унапређиване родне равноправности, за период 2009-2015. године, као и њеног сукцесора, Националну стратегију за родну равноправност за период 2016-2020. године са Акиионим планом 2016-2018. године. Потоња стратегија донета је на иницијативу Кординационог тела за родну равноправност основаног 2014. године, чија је улога да разматра сва питања и да координира рад органа државне управе у вези са родном равноправношћу. Како бисмо детаљно истражили захтеве у погледу остваривања родне равноправности у Републици Србији, у овом раду ћемо, из перспективе оквира законодавно-правног система, анализирати три главна документа којима се пропагира поштовање родне равноправности у периоду од 2009. до 2020. године: Националну стратегију за период од 2009. до 2015. године, Акииони план, те Националну стратегију за период од 2016. до 2020. године. Пошто употреба родно осетљивих термина није само правно већ и језичко питање, неопходно је и да институције које се баве језичким питањима и језичком политиком размотре могућност остваривања родне равноправности у самом језику. С тим у вези, Одбор за стандардизацију као релевантно језичко тело изнео је став да је употреба именица женског рода за именовање женских звања и занимања могућа само уколико су облици нормирани у српском језику. Јавност у Србији подељеног је мишљења у вези са оваквим ставом - на једној страни су они који су сагласни са ставом Одбора за стандардизацију, док су на другој они који се залажу за употребу именица женског рода са значењем звања и занимања без обзира на то да ли су оне нормиране. С обзиром на овакво стање, неопходно је размотрити сва могућа језичка средства искоришћена за остваривање родне равноправности у правним документима, не би ли се пронашао начин да се оствари баланс између језичких и правних законитости. 
Рад је организован на следећи начин: после уводног дела, следи теоријско-методолошки део у коме представљамо претходна истраживања која се директно или индиректно баве питањем родне равноправности, препознајемо основне карактеристике докумената законодавно-правног стила, те идентификујемо критеријуме за нашу анализу и описујемо корпус. У трећем поглављу, именованом као Анализа родно осетљивих термина у правним документима, најпре укратко анализирамо захтеве изнете у релевантним правним документима којима се прокламује родна равноправност у Републици Србији, а онда вршимо лингвостилистичку анализу тих докумената. Након извршене анализе, у четвртом поглављу дајемо одговарајући закључак.

\section{2. Теоријско-методолошки део}

\section{1. Родно осетљиви термини у теорији и пракси}

Употреба родно осетљивих термина једна је од централних тема социолингвистичких студија (FILIPOVIĆ 2009), женских родних студија (SAVIĆ 1995; 1996; SAVIĆ I DR. 2009), те чисто лингвистичких студија (IVIĆ 1960; 1989; NIKOLIĆ 2002-2003; ĆORIĆ 2008; IGNJATOVIĆ 2017). У лингвистичким истраживањима као једно од главних питања препознаје се (не)оправдана „маргинализација” термина којима се обележавају носиоци занимања у женском роду (IVIĆ 1960; 1989; NIKOLIĆ 2002-2003; ĆORIĆ 2008; IGNJATOVIĆ 2017). М. Ивић (1989: 35) тврди да је мушки род

„у српскохрватском, као и у толиким језицима света, у начелу семантички неутралнији од 'женског' што уједно објашњава његову употребну вредност, [a] у науци се одавно зна да могућности коришћења једног језичког решења стоје у обрнутој размери са његовом значењском обележеношћу."

Ауторка наводи и да, када се „представници одређених професија помињу сасвим уопштено, тј. само као такви, а не као конкретни појединци, по правилу се на њихов пол не обраћа пажња" (IVIĆ 1989: 42). Из лингвистичке перспективе, питање је, стога, може ли се уопште говорити о маргинализацији особа женског рода када се зна да је главна морфолошка одлика именица мушког рода одсуство наставка, док су именице женског рода обележене наставком (упореди учитељ- $:$ : учитель-ица), те да ли се у правним документима уопште помињу конкретне особе мушког и женског пола, или се само уопштено упућује на особе оба пола? Још једно важно питање јесте какве су законитости оквира у коме би родно осетљив термин требало да буде употребљен, конкретно, да ли правила законодавно-правног стила, коме припадају правни документи, 
дозвољавају употребу персоналних форми, као и да ли су морфолошке форме једини начин да се искаже родна равноправност.

У социолингвистичким истраживањима разматра се употреба родно осетљивих термина кроз потребу друштва да оствари једнакост на свим нивоима његовог деловања (FILIPOVIĆ 2009). У истраживањима која су правно заснована (SAVIĆ, KONSTANTINOVIĆ VILIĆ I PERUŠIĆ 2006: 59) наводи се да је језик закона, „основно средство којим законодавац исказује своје ставове, при чему се о ставовима законодавца закључује не само по садржају норми (порука) садржаних у закону, већ и по самом језику који законодавац користи”. Аутори примећују да се родна несензитивност српског језика често објашњава језичким стандардима и природом српског језика, при чему, српски језик називају родно несензитивним због тога што се не употребљавају увек морфолошка средства за именовање женских звања и занимања. Питање је да ли је уопште реч о родној несензитивности јер се родна сензитивост у српском језику може исказати не само морфолошким него и синтаксичким средствима.

\section{2. Методологија анализе корпуса}

На основу увида у претходна истраживања приметили смо да је употреба родно осетљивих термина комплексно питање, како лингвистичко тако и соцолингвистичко и правно. Како смо већ истакли, један од главних методолошких проблема ранијих истраживања јесте сужена перспектива из које се посматра употреба родно осетљивих термина. Да бисмо сагледали проблем употребе родно осетљивих термина из свих углова, у овом делу ћемо најпре укратко размотрити карактеристике законодавно-правног стила којим су писани правни документи које анализирамо.

Законодавно-правни стил се издваја као један од подстилова административног стила, а под њиме се подразумева „језички израз законских прописа, одлука, указа, директива, резолуција, статута, итд.” (TOŠOVIĆ 2002: 355). Законодавно-правни подстил одликује се „сувоћом, прецизности и једнообразности" (2002: 369). На синтаксичком плану доминирају просте реченице, а често се у функцији реченица јављају „изрази и конструкције, тачније кондензоване синтагме” (2002: 364). На морфолошком плану овај стил карактерише обезличеност, а деперсонализацији доприноси „честа употреба 3. лица у неодређено-личноме значењу" (2002: 363). Што се лексичког плана тиче, ограничен је спектар употребних лексема, сведен на општеупотребну и терминолошку лексику, с обзиром на то да је реч о стилу који се одликује слабом емоционалношћу и шаблонизацијом. У документима законодавно-правног стила неопходна је употреба обезличених форми и једнозначних термина. 
Природа ових докумената онемогућује употребу вишезначних појмова, а многи од морфолошких облика, који се препознају као једини начин исказивања родне равноправности у правним документима, управо јесу вишезначни (нпр. тренерка је жена тренер и одевни предмет). Питање је да ли се овакве именице које су вишезначне користе у документима законодавно-правног стила, и ако се не користе, које их форме мењају, те да ли се на тај начин може испоштовати родна равноправност.

У нашем раду ћемо, како бисмо разрешили комплексно питање употребе родно осетљивих термина, из угла законодавно-правног оквира идентификовати правне документе који се баве овим питањем, утврдити на који начин прокламују поштовање родне равноправности, те да ли су и колико прецизно постављени њихови захтеви који се тичу српског језика. Онда ћемо спровести лингвостилистичку анализу примера које смо ексцерпирали из корпуса, како бисмо утврдили спектар језичких средстава којима се родна равноправност остварује у српском језику, као и да ли су таква језичка средства употребљена у складу са законитостима језичког плана законодавно-правног стила. Поређењем захтева за остваривање равноправности изнетих у правним документима и језичких средстава ексцерпираних из правних докумената утврдићемо да ли и на који начин јединице употребљене у правним документима доприносе реализацији захтева које ови документи прокламују.

Основна претпоставка од које у овом истраживању полазимо јесте да ће употреба језичких средства за именовање женских звања и занимања у правним документима директно бити условљена формалним захтевима које документи за спровођење родне равноправности садрже, прецизније да ће сами правни документи садржати језичка средства помоћу којих ће се спроводити активности које су таквим документима прокламоване. Циљ нам је, са једне стране, да анализом правних докумената из угла законске регулативе препознамо активности помоћу којих би родна равноправност требало да се спроводи. Са друге стране, циљ нам је да лингвостистичком анализом утврдимо сва могућа језичка средства за остваривање родне равноправности у правним документима, те да препознамо разлоге који утичу на употребу таквих средстава.

Први део истраживачког корпуса чине Национална стратегија за побольшане положаја жена и унапређиваюе равноправности полова за период од 2009. до 2015. године, Акциони план за спровођене националне стратегије за поболшане положаја жена и унапређиване родне равноправности за период од 2010. до 2015. године

4 Приликом кодирања примера из овог документа користили смо скраћеницу АП. 
равноправности на националном нивоу. ${ }^{5}$ Из овог корпуса ексцерпирано је укупно 64 примера којима се у српском језику именују женска звања и занимања. У првом кораку јединице су селектоване, прочитане и кодиране тако што је праћен хронолошки принцип појављивања у правним документима ([НС01], [НС02]... [НС40]; [АП1], [АП2]... [АП9]; [ЕП01], [ЕП02]... [ЕП15]). У другом кораку извршена је детаљна анализа на основу поделе именица женског рода са значењем звања и занимања изнете у раду Б. Ћорића (2008). Како Ћорић (2008) наводи, све именице овог типа у српском језику могу се класификовати у три групе: неизведена именица неутрализована с обзиром на пол (нпр. уредник), изведена именица маркирана с обзиром на пол (нпр. уредница) и аналитичка форма (нпр. жена уредник). Под неизведеном именицом која је неутрализована с обзиром на пол подразумевају се именице мушког рода које су у српском језику немаркиране, док се под изведеним именицама маркираним с обзиром на пол подразумевају именице женског рода које имају наставак. Аналитичке форме су синтаксичке форме за именовање звања и занимања и оне се у српском језику могу реализовати како помоћу синтагми (нпр. жена уредник) тако и помоћу синтаксичких конструкција (нпр. жена из области уредништва). Други део истраживачког корпуса чине Устав Републике Србије, Закон о равноправности полова, те Национална стратегија за родну равноправност за период од 2016. до 2020. године са Акционим планом за период од 2016. до 2018. године. Потоњи документи предмет су анализе из перспективе правне регулативне, али не и језичке анализе.

\section{3. Анализа родно осетљивих термина у правним документима}

Ово поглавље састоји се из два дела. У првом делу идентификујемо правне документе којима се прокламује родна равноправност у Републици Србији, те захтеве у вези са остваривањем родне равноправности изнете у њима, да бисмо, у другом делу овог поглавља, анализирали језик тих докумената.

\section{1. Анализа правних докумената}

У овом делу рада ћемо, из перспективе оквира законодавноправног система, анализирати три најзначајнија документа у вези са спровођењем родне равноправности у Републици Србији у претходном периоду: Наиионалну стратегију за период од 2009. до 2015. године, Акцииони план, те Националну стратегију за период од 2016. до 2020. године. Национална стратегија за побольите положаја жена и унапређива-

5 Приликом кодирања примера из овог документа користили смо скраћеницу ЕП. 
не родне равноправности за период од 2009. до 2015. године представила је систематско решење проблема родне неравноправности. Уколико занемаримо остале сегменте родне равноправности, и фокусирамо се искључиво на родну осетљивост језика, примећујемо да је Стратегија предвиђала ту категорију у две области. У области образовања, наводи се развијање родно сензитивних, антидискриминаторних и секуларних програмских садржаја и родно осетљивог језика на свим нивоима образовања, укључујући и студије рода. С тим у вези, предвиђа се увођење употребе родно осетљивог језика у школске програме (Национална стратегија за побољшање положаја жена и унапређивање равноправности полова 2009-2015. године, стр. 20, т. 4), покретање питања стандардизације језика у институцијама, покретање програма за редовне студије рода на заинтересованим факултетима, те помоћ при укључивању студија рода у систем високог школства. У погледу родне равноправности језика у области јавних гласила, Стратегија налаже подстицање употребе несексистичког и родно сензитивног језика, поштовање правила српског језика о слагању у роду, броју и у падежу, употребљавање женског рода у вези са звањима и са занимањима које обављају жене, избегавање израза и термина који су последица стереотипа и предрасуда о половима, те елиминисање увредљивих израза према женама, а посебно према вишеструко дискриминисаним групама. Дакле, очигледно је да се и у Cmpameгији налаже поштовање правила српског језика, конкретно правила реализованих на морфолошком плану, што нам имплицитно сугерише да би остваривање родне равноправности из угла правне регулативе требало да се врши само помоћу таквих средстава.

Сама Стратегија је захтевала спровођење у пракси, што је постигнуто доношењем још једног законског документа који разматрамо, Акционог плана, у коме су утврђене активности за остваривање циљева Стратегије 2009-2015. године. У погледу родно осетљивог језика, задатак Акционог плана био је увођење недискриминаторне терминологије и стандардизацију српског језика у погледу правилне употребе рода, што опет упућује само на употребу морфолошких средстава. С обзиром на то да нису све именице којима се именују звања и занимања лексикализоване, па самим тим ни део стандардне употребе српског језика, овај документ пропагирао је прилагођавање природе и структуре српског језика захтевима законских докумената, што имплицитно налаже да би језичка средства српског језика требало да буду подређена потребама законских докумената. Потоње је апсолутно у супротности са законима језика. Језик јесте флексибилан систем и он се апсолутно прилагођава захтевима друштва јер је његова основна сврха омогућавање комуникације међу говорницима, али и он сам поседује правила која морају бити задовољена 
како би опстао као стабилан систем. Управо ово је потврдио и Одбор за стандардизацију, изневши став о употреба генерички мушког рода или других језичких средстава за случајеве у којима облици женског рода нису нормирани.

Још један од докумената који се намеће за разматрање јесте Наиионална стратегија за период од 2016. до 2020. године, којом се валидирају активности за спровођење родне равноправности донете претходном Стратегијом. Национална стратегија за период од 2016. до 2020. године показује да се препорука из претходне Националне стратегије у вези са коришћењем родно осетљивог језика није потпуно реализовала у пракси (Национална стратегија за период од 2016. до 2020. године, стр. 4), па се у новој Cmратегији поново налазе одредбе у вези са родном сензитивношћу у образовању и медијима. У новој Cmpamегији констатује се да образовни процес у Републици Србији није родно осетљив (Национална стратегија за период од 2016. до 2020. године, т. 1, стр. 23), као и да је мали број медија који користе родно осетљив језик, док се родна сензитивност у законским документима уопште не разматра. Очигледан проблем ових захтева препознаје се у чињеници да се њихово поштовање препознаје само кроз употребу морфолошких средстава српског језика. Питање је зашто ниједан од коментарисаних докумената не разматра синтаксичка средства којима се апсолутно равноправно могу именовати звања и занимања у српском језику. Питање је и ако се оба ова средства могу пронаћи управо у документима који прокламују родну равноправност, да ли би њихова употреба у другим сферама које Cmpaтегија идентификује, нпр. у образовању и медијима, значила поштовање родне равноправности. Циљ нам је да лингвостилистичком анализом законских докумената која следи у наредном одељку препознамо доступна језичка средства за исказивање родне сензитивности не би ли се, увидом у шири спектар средстава, олакшала имплементација законских прописа у свим сферама јавног живота у Републици Србији.

\section{2. Лингвостилистичка анализа правних докумената}

У овом делу, из лингвостилистичке перспективе, анализирамо правне документе којима се прокламује родна равноправност у Републици Србији. Као што је наведено у одељку 2.2, анализа корпуса који је прикупљен за потребе овог истраживање ослања се на Ђорић (2008). Ћорићевој аналитичкој форми одговарају, у документима које смо разматрали, синтаксичка средства каква су независне координиране синтагме, које смо дали под $1 \mathrm{~A}$, или сложене зависне именичке синтагме, дате под 1Б, односно падежне конструкције, дате под 1Б*, или синтаксичке конструкције, дате под 2. Идентификовали смо и именице које су марки- 
ране с обзиром на пол, што је дато под 3. Анализа свих ексцерпираних родно осетљивих термина показује да су синтаксичка средства чешће у употреби од морфолошких. У наставку ћемо дати квалитативну анализу ексцерпираних примера.

\section{1) Синтагме:}

А) жена и мушкараи [ЕП1], право жена и мушкараиа да буду имаоии [ЕП2];

Б) жена приправник [ЕП3]; жена власнииа компанија и радни [АП01], жена пореских обавезника [АП02], жена тренера [АП03], жена судија [АП04], жена специјалиста [АП05], жене у физиии [АП06], жене у математици [АП07];

$Б^{*}$ жене са инвалидитетом [НС01], избегле жене [НС02], жене припаднице националних манина и мағинских група [НС03], старије жене [НС04], припаднице маюинских [НС05], наиионалних и верских група [НС06], жене другачије сексуалне оријентације [НС07], жене са инвалидитетом [НС08], сеоскежене [НС09], жена међу председнииима [НС10], жена међу предавачима [HC11], жена међу магистрима [НС12]; жена међу докторима наука [НC13];

2) Синтаксичке конструкције: о положају жена из вишеструко дискриминисаних група [НС14], жена жртава рата, а нарочито избеглих и интерно раселених жена [НС15], избеглице/раселене жене [НС16], жртве рата [НС17], жене које живе у истополним заједницама [НС18], жене са психички измененим понашанем [НС19], жене зависне од алкохола, дроге и/или медикамената [НС20], жене са ХИВ/АИДС вирусом [HC21], хроничне болеснице [HC22], сиромашне жене [HC23], женска деца [HC24], жене из сеоских средина и друге витеструко дискриминисане групе жена с инвалидитетом [HC25].

3) Морфолошки облици: службеница [АП08], координаторка [АП09], новинарка [АП10], саветнииа [АП11], консултанткиюа [АП12], мигранткиюе [АП13]; грађанка [НС26], подносителька [НС30], потпреседнице [НС31], председнице [НС32], министарке [НС33], домаћице [НС34], пољопривреднице [НС35], ректорка [НС36], научнииа [НС37], експерткиға [НС38] стручғакиға [НС39].

Размотрићемо најпре морфолошка средства и утврдити разлоге њиховог појављивања. Именице које су маркиране с обзиром на пол садрже суфиксе као што су -ица, -арка, -ка, -киюа. Најфреквентније су именице са суфиксом -ица: председница, саветница, добитница, а најмање фреквентне оне са суфиксом -киюа (експерткиюа, стручюакиюь). У употреби су како именице домаћег порекла (председнии, министарка) тако и оне које су страног порекла (мигранткиюа, експерткиюа, стручғакиюа). Како анализирани примери показују, идентификована морфолошка средства употребљавају се само када се тачно зна о коме је реч, или се тражи особа тачно одређеног рода (... а две су биле потпредседнииее Скупштине, од којих је 2002. године једна изабрана за председнииу... [HC31]).

Што се синтаксичких средстава тиче, пронашли смо синтагме као што су: жена међу магистрима; жена међу докторима; младих жена и жена из вишеструко дискриминисаних група; жена међу предавачима; жене међу народним посланииима; жене и мушкарии; жена са инвалиди- 
тетом; жене приправнице. Детаљном анализом утврдили смо да се синтаксичка средства употребљавају: 1) када не постоји адекватна именица женског рода (као у примеру право жена и мушкараца да буду имаоци); 2) када је именица женског рода вишезначна (као у примеру жена међу посланицима јер именица посланица има неколико различитих значења, в. примере 4-8); 3) када би требало избећи именицу која није лексикализована и која може имати и негативно значење (као у примеру жена међу предавачима уместо жена међу предавачицама). Синтаксичка форма се користи и како би се постигао јачи прагматички ефекат: нпр. жена приправник, а не приправница у примеру: ...da zapošljavaju žene pripravnike u skladu sa njihovim veštinama, kvalifikacijama i pozicijama koje se tradicionalno smatraju „muškim” i obrnuto [ЕП3]). На овај начин фокус је на опозицији мушки : женски род, чиме се прагматички гледано остварује јаче контрастирање него када би се употребила именица женског рода.

4. Посланица (писмена порука, обично група људи);

5. посланица (службена порука владара народу или законодавном телу; порука црквеног поглавара свештенству и пастви);

6. $\quad$ посланица (писмо у стиховима као врста књижевног дела);

7. посланица (апостолско писмо у Новом завету: апостола Павла);

8. посланица (у значењу женска особа посланик) (према РСЈ 2011, стр. 964).

Анализирани правни документи садрже и сложене синтагме као што су жена власница, жена предузетница, жене министарке, предузетнице учеснице. Лингвостилистичком анализом утврдили смо да се овим синтагмама постиже двоструко мапирање особа женског пола - жене предузетнице су предузетнице женског пола - док такве синтагме са именицама мушког рода уопште нису доступне (нпр. мушкараи, предузетник). На овај начин се језик правних докумената усложњава, чиме се крши један од основних принципа самог законодавно-правног стила којим су ови документи писани - једноставност. Овакви примери показују да постоје случајеви у којима потреба за спровођењем родне равноправности не поштује ни језичке ни правне принципе, а како је наша анализа показала, родна равноправност се неометано остварује само када се оба ова принципа поштују.

На основу свега изреченог евидентно је да би адекватна употреба родно осетљивих термина, гледано из лингвостилистичке перспективе и перспективе законодавно-правног оквира, морала да зависи од чинилаца као што су: 1) карактеристике језика у коме су родно осетљиви термини употребљени, 2) карактеристике пошиљаоца поруке (правни документи), 3) исправно декодирање знака, под чиме се подразумева да би ствараоци правних докумената и они којима су документи намењени 
морали да познају значења употребљених родно осетљивих термина. С обзиром на то да је језик у правним документима употребљен у функцији обезличавања и конкретизације, употреба синтаксичких средстава је сасвим оправдана онда када морфолошка средства нису доступна из лингвостилистичких или прагматичких разлога. Њима се апсолутно равноправно износи став органа власти, чиме се, правно гледано, имплицитно прокламује равноправност.

\section{4. Закључак}

На основу лингвостилистичке анализе релевантних правних докумената идентификовали смо доступна морфолошка и синтаксичка средства за остваривање родне равноправности и утврдили да су синтаксичка средства чешћа у употреби. Анализирани примери показују да се синтаксичка средства користе уколико: 1) морфолошка форма није лексикализована, 2) морфолошка форма има више значења, 3) морфолошка форма има и негативно значење. Истраживање је показало и да се употребом синтаксичке форме може: 1) постићи јачи прагматички ефекат, 2) избећи стварање тзв. „тешких” конструкција, којима се оптерећује форма правних докумената. Гледано из перспективе законских докумената, утврдили смо да су захтеви у вези са родном сензитивношћу језика уско постављени и да би требало да се прошире и на доступна синтаксичка средства, која су у српском језику апсолутно релевантна, те која су, како смо утврдили, у појединим случајевима боље решење од морфолошких средстава. Наше истраживање је потврдило да је неопходно пронаћи баланс између стремљења ка успостављању родне равноправности употребом родно осетљивих термина, и традиционалних родних одредница за одређена занимања, што би требало да буде питање струке, узимајући поменуте специфичности српског језика у обзир, а не само правно питање.

\section{Цитирана литература}

IVIĆ (1989): ИВИЋ, Милка. Нека запажања о броју и роду у српскохрватском језику. Јужнословенски филолог, XLV, 27-44.

IVIĆ (1960): ИВИЋ, Милка. Обележавање именичког рода у српскохрватском књижевном језику. Наш језик, 7-10, 192-211.

IGNJATOVIĆ (2017: ИГЊАТОВИЋ, Наташа. Родно осетљив језик у јавном дискурсу. Philologia Mediana, 9, 479-499. https://izdanja.filfak.ni.ac.rs/casopisi/2017/philologia-mediana-9-2017

NIKOLIĆ (2002-2003): НИКОЛИЋ, Мирослав. Природан и граматички род именица. Наш језик, 3-4, 181-194.

SAVIĆ I DR. (2009): САВИЋ, Свенка, ЧАНАК, Маријана, МИТРО, Вероника, 
и ШТАСНИ, Гордана. Род и језик. Нови Сад: Женске студије и истраживања и Футура публикације.

SAVIĆ, KONSTANTINOVIĆ VILIĆ I PETRUŠIĆ (2006): САВИЋ, Свенка, КОНСТАНТИНОВИЋ ВИЛИЋ, Слободанка, и ПЕТРУШИЋ, Невенка. Језик закона - карактеристике и родна перспектива. Право и језик, 55-63.

SAVIĆ (1996): САВИЋ, Свенка. Језик и пол: истраживана код нас. Београд: Женске студије, бр. 2.

SAVIĆ (1995): САВИЋ, Свенка. Језик и пол: истраживаға у свету. Београд: Женске студије, бр. 1.

TOŠOVIĆ (2002): ТОШОВИЋ, Бранко. Функиионални стилови. Београд: Београдска књига.

FILIPOVIĆ (2009): ФИЛИПОВИЋ, Јелена. Моћ речи : огледи из критичке соииолингвистике. Београд: Задужбина Андрејевић.

ĆORIĆ (2008): ЋОРИЋ, Божо. Творба именииа у српском језику. Београд: Друштво за српски језик и књижевност.

\section{Извори}

Акциони план за спровођење националне стратегије за побољшање положаја жена и унапређивање родне равноправности за период од 2010. до 2015. године, Службени гласник РС. Бр. 67/10 (2010)

Закон о равноправности полова, Службени гласник РС. Бр. 104/09 (2009)

Национална стратегија за побољшање положаја жена и унапређивање равноправности полова за период од 2009. до 2015. године, Службени гласник РС. Бр. 15/09 (2008)

Национална стратегија за родну равноправност за период од 2016. до 2020. године са Акционим планом за период од 2016. до 2018. године, Службени гласник РС. Бр. 55/05 (2016)

Речник српскога језика, (уредник Мирослав Николић), Нови Сад: Матица српска, 2011.

Устав Републике Србије, Службени гласник РС. Бр. 98/2006 (2006) 
Ivana Mitić

Andrej Blagojević

\section{THE ANALYSIS OF GENDER- SENSITIVE TERMS IN LEGAL DOCUMENTS}

The paper analyses gender sensitive terms used in Serbian legal documents from two different perspectives: while morphological and syntactic devices as the means of representing gender sensitive terms are examined from the linguo-stylistic perspective, Serbian legislative documents containing the acts of gender equality realization are investigated from the legal regulation perspective. The aim of the research is to relate the results of linguo-stylistic analysis to the results obtained by analyzing legislative activities and legal regulations proclaimed in Serbian legal documents in order to find out whether the use of gender sensitive terms in legal documents is exclusively for the linguistic purpose. The research corpus comprises several legal documents: The National Strategy for improving the position of women and promoting gender equality (2009-2015), The Plan of Action for the Implementation of the National Strategy for Improving and Promoting Gender Equality (2010-2015), The National Strategy for improving the position of women and promoting gender equality (2016-2020), The Plan of Action for the Implementation of the National Strategy for Improving and Promoting Gender Equality (2016-2018). Besides them, the research corpus also includes The Constitution of the Republic of Serbia, The European Charter on Gender Equality at National Level, and The Law on Gender Equality. The results of linguo-stylistic analysis confirm that the legal documents issued in the period of 2009 to 2015 contain some gender sensitive terms realized through various morphological and syntactic devices, the latter being more numerous. The use of syntactic elements occur in cases where 1) the morphological form is not lexicalized, 2) the morphological form has several meanings, 3) the morphological form has a negative meaning. The results obtained by analysing legal framework indicate the presence of only one domain of language resources and therefore it can be concluded that these resources have to be expanded in order to achieve the gender equality realization in all spheres of society.

Keywords: linguo-stylistic, sociolinguistics, gender sensitive terms, legislative frame, impersonality 